\title{
The Professional Competences of Native English Speaking Teacher as Viewed by Students
}

\author{
Ruqoyah Yulia Hasanah Dhomiri ${ }^{1}$, Ekaning Dewanti Laksmi ${ }^{1}$, Nur Mukminatien ${ }^{1}$ \\ ${ }^{1}$ Pendidikan Bahasa Inggris-Universitas Negeri Malang
}

\section{INFO ARTIKEL}

\section{Riwayat Artikel:}

Diterima: 20-01-2020

Disetujui: 14-12-2020

Keywords:
native teacher;
professional competences;
EFL students
guru penutur asli;
kompetensi profesional;
Siswa kelas XI

\section{Alamat Korespondensi:}

Ruqoyah Yulia Hasanah Dhomiri

Pendidikan Bahasa Inggris

Universitas Negeri Malang

Jalan Semarang 5 Malang

E-mail: ruqoyah.yulia@gmail.com

\begin{abstract}
ABSTRAK
Abstract: Millennium development requires schools to prepare their students to have proper English skills. It makes some schools hire native speaker as the expert of English. However, it is known that not all native speaker can teach English. They may be an expert in using English, yet not the expert of teaching English because the lack of professional competences. In this case, it is needed to investigate the native teacher professional competences based on the students' view, since the students were the people who experienced to be taught by the native teacher. In this study, it was found that the native teacher seemed to be more suitable for teaching the higher achiever students since they could follow the native teacher's explanations and instructions. Meanwhile, for the lower achiever students, being taught by the native teacher was challenging. This study aimed to investigate the professional competences of a native teacher as viewed by the students.
\end{abstract}

\begin{abstract}
Abstrak: Perkembangan Milenium mengharuskan sekolah mempersiapkan siswa mereka untuk memiliki keterampilan bahasa Inggris yang memadai. Hal itu membuat beberapa sekolah mempekerjakan penutur asli sebagai guru bahasa Inggris. Namun, diketahui bahwa tidak semua penutur asli dapat mengajar bahasa Inggris. Mereka mungkin ahli dalam menggunakan bahasa Inggris, namun belum tentu ahli mengajar bahasa Inggris karena kurangnya kompetensi profesional. Dalam hal ini, di perlukan penyelidikan terhadap kompetensi profesional guru penutur asli bahasa Inggris berdasarkan pandangan siswa, karena siswa adalah orang-orang yang berpengalaman dalam diajar oleh penutur asli. Dalam penelitian ini, ditemukan bahwa guru penutur asli bahasa Inggris tampaknya lebih cocok untuk mengajar siswa berprestasi karena mereka dapat mengikuti penjelasan dan instruksi guru tersebut. Sementara itu, bagi siswa berprestasi rendah, diajar oleh guru penutur asli bahasa Inggris adalah sebuah tantangan.
\end{abstract}

The rapid development of science and technology, in which many of the sources of knowledge (such as books, journals, and articles) and the latest technologies use English for the instructions of using it increases people's awareness of the importance of learning English. In addition, the higher interest of human travel from one country to another also affects people's awarenes s to learn English as an international language used by almost all countries around the world. Thus, more and more people are thinking of learning English with the right English teacher or experts. Therefore, there are more schools, language centers, and English courses that offer to learn English with native speakers (Wong, 2009).

In this era, there are many schools and English courses that offer English learning with native speakers, including in Indonesia. Native speakers are often considered as the ideal English teacher. Numerous scholars reveal that native speakers are the most ideal language teachers and the best choice for teaching English (Hu \& Lindemann, 2009; Jin, 2005; McKenzie, 2008; Reis, 2011; Scales, Wennerstrom, Richard, \& Wu, 2006; Timmis, 2002). This is because native speakers are considered as experts in using English appropriately.

However, in fact, the students not only need a teacher who is expert in using English (Maum, 2002), but also a teacher who is qualified in the field of teaching English and has adequate competences as a teacher. A qualified and competent teacher is the ideal teacher for the students' learning success. It is in line with (Al-Khairi, 2015) who revealed that an ideal language teacher is a teacher who has personal and professional qualities. Professional quality here includes the teacher's ability to master the material on the subject matter of English, the teacher's ability to teach and the teacher's expertise in establishing good 
communication with students so students are more opened to express their learning difficulties and the teacher can more easily handle student learning difficulties, so the teacher it becomes an effective language teacher.

Then some questions regarding the professional competences of a native teacher arise; Is the native teacher competent and qualified to teach English? Does the native teacher master the contents of the subject matter? Is the native teacher able to help students' learning difficulties? Does the native teacher have a good personality for students' character building? Does the native teacher establish good communication with the social environment? Then, this study aims to investigate the professional competences of a native teacher as viewed by students, which cover the subject matter, pedagogical, personal, and social competences. Henceforth, the research problems are stated as follows. First, how do the students perceive their native teacher regarding the professional or subject matter competence in English Language Teaching?. Second, how do the students perceive their native teacher regarding pedagogical competence in English Language Teaching?. Third, how do the students perceive their native teacher regarding personal competence in English Language Teaching?. Fourth, how do the students perceive their native teacher regarding social competence in English Language Teaching?

\section{NATIVE SPEAKER TEACHER}

The native speaker absolutely can speak English more fluent and accurate than the non-native speaker. The native speaker has the competences of sociolinguistics that know how to use the language properly according to its context (Braine, 2010). Although it is not a doubtful issue that non-native English speaking teachers usually have deficient linguistics when using English (Medgyes, 2001), however, the non-native teacher with high proficiency in English will provide good input for students' English achievement (Van Canh \& Renandya, 2017). It is in line with (Maum, 2002) states that teaching English not merely about people who are fluent in English from a young age and use English as the main language, but teaching English must be done by people who have competence and qualifications in teaching English.

Although the native is absolutely better in pronouncing English words, more fluent in speaking and also more comprehend in using English based on the real-life context rather than the non-native, it does not mean that native speaker is more competent in English language teaching. The natives acquire English subconciously (Krashen, 1985) sometimes they are just using the language. It means that they are just saying the words, sentences or expressions in English without knowing how to explain to the students the grammatical rules or why it works like that. In this case, it is needed to investigate whether or not the native teacher is an ideal teacher in English language teaching.

\section{IDEAL LANGUAGE TEACHER}

An ideal language teacher is closely related to the professional competences of the teacher (Al-Khairi, 2015). Thus, a teacher who leads the students' success in learning the language ideally should be required to have professional competences in order to meet the goals of education. Teacher's Professional Competences is a set of abilities that must be possessed by a teacher in order to meet the success of teaching. Every professional language teacher in Indonesia is required to possess certain standards of competencies that are systematically set in law no 14 of (2005) about professional competences of a teacher covering the subject matter, pedagogical, personal, and social competences.

Subject matter competence is the mastery of learning material widely and deeply, which includes the mastery of materials of English as the subject matter stated in the curriculum at school. Meanwhile, pedagogical competence is the ability to understand the students, designing and implementing the learning materials, evaluating the learning outcomes, and developing the students' potentials. Then, personal competence is the ability of a teacher in managing his or her emotional intelligence, since it can affect the students' motivation in learning and also inspire them to be a person like their teacher. Social competence is the teacher's ability to communicate and interact with the social environment, especially establish good communication with the students. Thus, being a teacher is a professional job that cannot be replaced by a machine.

\section{METHOD}

This study was conducted to analyze, describe, then understand the native teacher's professional competences as viewed by the students. According to the objective of this study, a descriptive case study design was employed, since the findings were obtained by describing a real-life phenomenon in the natural setting. The data were obtained from questionnaire and interview which consist of any information about students' perceptions. The students who were selected as the research subject fulfilled the criteria stated in this study. They were taught by a well-trained and experienced native teacher. The native teacher had numerous experiences in teaching English 


\section{FINDINGS \& DISCUSSION}

The following are the results of this study obtained from the information of the instruments and the discussion of findings which include the analysis results of subject matter, pedagogical, personal and social competences of the native teacher as viewed by students. Asking the students' perception of their teachers aimed to make the learning process in the classroom more effective (Kiczkowiak, 2017).

\section{The Native Teacher's Subject Matter Competence as Viewed by Students}

Subject matter competence is the mastery of learning material widely and deeply, which includes the mastery of materials of English as the subject matter stated in the curriculum at school. Teacher's subject matter knowledge significantly influences students' performance (Kiamba, Mutua, \& Mulwa, 2018). Thus, a language teacher should have the knowledge of subject matter, also have the ability to deliver the learning material and recognize how to make students learn and use the language. In this study, there were 8 criteria of teacher's subject matter competence inspired by The Regulation of Education Minister Number 16 of (2007), these criteria include the ability of native speaker to teach 4 language skills and 3 language components. Based on the results of the questionnaire, it was known that most of the students agreed that the native teacher had sufficient knowledge in the subject matter of English as shown in table 1.

Table 1. The native teacher's subject matter competence as viewed by students

\begin{tabular}{|c|c|c|c|c|c|c|c|c|}
\hline \multirow{2}{*}{ Statements } & \multicolumn{2}{|c|}{ SA } & \multicolumn{2}{|c|}{$\mathbf{A}$} & \multicolumn{2}{|c|}{ D } & \multicolumn{2}{|c|}{ SD } \\
\hline & $\mathbf{N}$ & $\%$ & $\mathbf{N}$ & $\%$ & $\mathbf{N}$ & $\%$ & $\mathbf{N}$ & $\%$ \\
\hline She is an ideal model for learning pronunciation & 20 & 55.6 & 15 & 41.7 & 1 & 2.8 & & \\
\hline She can explain grammar using clearly explanations & 12 & 33.3 & 20 & 55.6 & 4 & 11.1 & & \\
\hline She can provide any new vocabulary & 9 & 25.0 & 24 & 66.7 & 3 & 8.3 & & \\
\hline She can explain any difficult words which are questioned by the students & 8 & 22.2 & 27 & 75.0 & 1 & 2.8 & & \\
\hline She contributes a lot on students' listening progress & 14 & 38.9 & 20 & 55.6 & 1 & 2.8 & 1 & 2.8 \\
\hline She encourages students to practice using English in speaking activities & 13 & 36.1 & 18 & 50.0 & 5 & 13.9 & & \\
\hline She can teach reading well & 12 & 33.3 & 23 & 63.9 & 1 & 2.8 & & \\
\hline She encourages students to be able to create any writing products & 4 & 11.1 & 23 & 63.9 & 7 & 19.4 & 2 & 5.6 \\
\hline
\end{tabular}

\section{Note SA: Strongly Agree; A: Agree; D:Disagree; SD: Strongly Disagree}

Some students stated that the existence of native teacher could improve their English achievement since the native teacher could use English appropriately and used English every time she taught. For instance, they seem to have listening practice every time the native teacher explained the materials, thus it could improve their listening skill. They also could practice speaking English with the native speaker using some vocabulary used in the real-life context. Nevertheless, in this study, it was found that being taught by native teacher was challenging for some students who lacked confidence in speaking English and several other students who did not have the ability to speak English due to lack of vocabulary. Actually, some of these students understand what was said by the native teacher, and had any ideas to express, yet the limitations of using English become an obstacle for them to express their ideas.

However, although most of the students agreed that the native teacher had sufficient skill in writing and grammar, yet during the interview, almost the entire of the students stated that the native was not really mastering some materials of grammar and nearly never gave any feedback on the students' writing product. Some students said that the native sometimes could not answer the students' questions about grammar materials. The native teacher would find the answer and told the students to answer their questions in the next meeting. When it was confirmed to the native teacher, she stated that she did not know well about grammar or any complicated formulation of grammatical structures as usually being taught for Indonesian learners, most of the native speakers do the same. Additionally, most of the native speakers do not use perfect English grammar, especially in speaking. She would not emphasize more on grammar since the first goal of learning English is to be understood.

In teaching English, it does not only need someone who is able to speak English fluently in front of the class, yet the teacher should also help and motivate the students to understand the materials and the tasks given. Therefore, the class will be more meaningful with the existence of native speaker teacher (Kiczkowiak, 2017).

\section{The Native Teacher's Pedagogical Competence as Viewed by Students}

Subject matter competence and pedagogical competence of a teacher actually have a relationship, because pedagogical competence also assesses how the teacher can make students easily understand the material on the subject matter, how to make the subject matter can be conveyed clearly and pleasantly. Teacher's pedagogical knowledge leads the EFL students' learning success (Azma \& Talebinejad, 2012). Therefore, students also need a teacher who has pedagogical or practical knowledge so 
that she knows how to facilitate the students' learning and how to make students successful in learning the target language, it is not merely about the teacher who can speak English fluently.

Table 2. The native teacher's pedagogical competence as viewed by students

\begin{tabular}{|c|c|c|c|c|c|c|c|c|}
\hline \multirow{2}{*}{ Statements } & \multicolumn{2}{|c|}{ SA } & \multicolumn{2}{|c|}{$\mathbf{A}$} & \multicolumn{2}{|c|}{ D } & \multicolumn{2}{|c|}{ SD } \\
\hline & $\mathbf{N}$ & $\%$ & $\mathbf{N}$ & $\%$ & $\mathbf{N}$ & $\%$ & $\mathbf{N}$ & $\%$ \\
\hline She can explain the material clearly and understandable & 8 & 22.2 & 21 & 58.3 & 7 & 19.4 & & \\
\hline She can make the classroom atmosphere more flexible and pleasant & 11 & 30.6 & 19 & 52.8 & 5 & 13.9 & 1 & 2.8 \\
\hline She uses sounds that can be heard by all students, with the appropriate intonation and & 21 & 58.3 & 13 & 36.1 & 2 & 5.6 & & 2.8 \\
\hline variations of sound when teaching & 9 & 25.0 & 20 & 55.6 & 7 & 19.4 & & \\
\hline She provides a variety of learning media, such as videos, audio, songs, games, and so on & 5 & 13.9 & 19 & 52.8 & 11 & 30.6 & 1 & \\
\hline She always goes around to every student in the class to check their work & 9 & 25.0 & 21 & 58.3 & 6 & 16.7 & & \\
\hline She always gives feedback correction on each assignment or student's work & 8 & 22.2 & 24 & 66.7 & 4 & 11.1 & & \\
\hline She help students solve the learning difficulties & 6 & 16.7 & 22 & 61.1 & 8 & 22.2 & & \\
\hline She uses technology (for instance: mobile phones, laptops, projector facilities, etc.) during & 18 & 50.0 & 16 & 44.4 & 2 & 5.6 & & \\
\hline the learning process & 12 & 33.3 & 17 & 47.2 & 7 & 19.4 & & \\
\hline $\begin{array}{l}\text { She speaks using slow and clear tempo in order to make the students more easily to } \\
\text { understand what was being explained }\end{array}$ & 16 & 44.4 & 19 & 52.8 & 1 & 2.8 & & \\
\hline She helps the students to improve their confidence in learning English & & & & & & & & \\
\hline She always shows her enthusiasm to teach the students & & & & & & & & \\
\hline
\end{tabular}

From the result of the questionnaire above, it is known that there were more students who perceived positive on the native teacher's pedagogical competence. Some students claimed that the native teacher could deliver the material well. The existence of native teacher in this school could motivate some students, especially those who were fond of English lessons, those who were always interested to practice speaking English and join extracurricular activities. However, during the interview, there were some students who claimed to have difficulty learning with the native teacher because they often did not understand what native teacher said and automatically they also did not understand what the native teacher was trying to teach and explain in front of the class. These students were those who did not like English subject and lack of vocabulary, thus it was difficult to follow what was conveyed by the native teacher, even though the native teacher tried to speak with clear intonation and pronunciation. In this study, it was clear that the students who had good achievements in English subject were easier to follow the teacher's instructions. The native teacher seems to be more suitable for teaching the upper level of students and those who are advanced in English (Topal \& Öztürk, 2017).

During the interview, some students also claimed that the native teacher sometimes could not explain any materials from the subject matter of English that could be easily understood by the entire of the students. Teacher's pedagogical knowledge leads to EFL students' learning success (Azma \& Talebinejad, 2012). Therefore, students also need a teacher who has pedagogical or practical knowledge so that he knows how to facilitate the EFL students' learning and how to make the students success in learning the target language, it is not merely about the teacher who can speak fluently English.

Although native teacher had any teaching experiences before she taught in Indonesia, yet her students were native of English and ESL students in America. The native teacher also claimed that the way of teaching ESL and EFL students was very different because the context of the use of English for the two types of students was different. According to Anchimbe (2006) in the ESL context, English is used in educational and professional contexts, it is used generally in any formal situation. Meanwhile, in the EFL context, English is just an additional language which is used to find a better job or for the International necessity. Therefore, many EFL students could not speak English fluently since they rarely used English in their daily communication.

In this case, the researcher tries to explore deeper information on whether the native teacher was able to help the students to solve the learning problem of her EFL students. Some EFL students who had good background knowledge of English claimed that native teacher could help their learning difficulties outside the classroom, and students could ask for any material that they still do not understand either during the recess or after school. However, some students who lacked the vocabulary and felt insecure to speak English with native teacher almost never complained about their learning difficulties.

In addition, during the interview, one of the students claimed that the native teacher sometimes found it difficult to explain the materials to the low achiever students. For instance, when the native teacher confirmed whether or not the entire students in class already understood what she already explained, this student honestly told that he did not understand, the native teacher tried to explain it again, yet when this student still did not understand it, the native teacher stop explaining it again, ignored the student, and moved to the next explanation. From this student's recognition, the researcher concluded that the native teacher still had not found the right approach and strategy to make all students understand the material presented. According to Wong (Wong, 2009), native teachers tend to be more successful in teaching advanced students. Therefore, it is clear that in this 
study the low achiever students found it difficult to learn English with native teacher, this was often caused by language barriers between the teacher and students. In addition, the use of full English during the lessons restrained them to maximally participate in class. Some of these students also admitted that they could not mix the English-Indonesian language when they tried to communicate with the native teacher since the native teacher did not know Indonesian language.

Although native teacher often provided any learning media to make it easier for students to understand the material being discussed, there were some students who claimed that they did not understand what the native teacher's mean because of the limitation of their English language that has been explained previously. Some students claim that they were not used to listening to English explanations and almost never had any conversations full using English. Thus, it was difficult for them to understand what was explained by the native teacher. Therefore, the native teacher asked for help and did collaborations with the non-native teacher sometimes, to explain what has been said by her to the students, yet sometimes this took a long time. Meanwhile, with the limited time given, the materials in the subject matter that should be delivered to the students were very numerous and dense.

\section{The Native Teacher's Personal Competence as Viewed by Students}

The personality of the teacher can make the students feel comfortable while studying in class. If the teacher is too strict, students might get scared and the teaching and learning process will run stiff. In this study, researchers only focused on some criteria which could be easily viewed by the students. Those criteria were inspired by Indonesian Law No. 14/2005 which are stated in the questionnaire below:

Table 3. The native teacher's personal competence as viewed by students

\begin{tabular}{llllccccc}
\hline \multirow{2}{*}{ Statements } & \multicolumn{2}{c}{ SA } & \multicolumn{1}{c}{ A } & \multicolumn{2}{c}{ D } & \multicolumn{2}{c}{ SD } \\
\cline { 2 - 9 } & $\mathbf{N}$ & $\mathbf{\%}$ & $\mathbf{N}$ & $\mathbf{\%}$ & $\mathbf{N}$ & $\mathbf{\%}$ & $\mathbf{N}$ & $\mathbf{\%}$ \\
\hline She is friendly & 20 & 55.6 & 15 & 41.7 & 1 & 2.8 & \\
She is a pleasant and flexible person & 14 & 38.9 & 20 & 55.6 & 2 & 5.6 & \\
She is a humorous person & 3 & 8.3 & 27 & 75.0 & 6 & 16.7 & \\
She is a role model and an inspiring teacher & 7 & 19.4 & 24 & 66.7 & 5 & 13.9 & & \\
\hline
\end{tabular}

Based on the result of the questionnaire above, it is known that most of the students agreed that the native teacher was friendly according to some students, especially students who had good achievements in English and often communicate with native teacher. They claimed that she was a flexible person and always respected others' opinions. She was a pleasant and kind person. The crucial thing of being a teacher for students is funny, patient, helpful, and kind (Anugerahwati \& Saukah, 2010). Although in class she tended to be assertive, yet outside the class when relax time, or during extracurricular after school, students claimed that she was a kind and easy-going person.

However, although in the questionnaire some students stated agree on the statement that the native teacher was a humorous person, yet during the interview, almost all of the students said that the native teacher almost never joked in class. This happened since Indonesian humor and American humor are absolutely different. According to (Nugroho, 2012) different people with different languages absolutely produce different jokes, he also added that jokes of one language cannot directly translate into another language. Thus, some Indonesian humor that was funny for students, yet it was not understood by the native teacher, and vice versa, if native teacher tried to relate one of the discussion material with humor which according to Americans' joke might be not funny for the students.

Although unable to bring humor in class, the native teacher was a role model for students, she was an inspiration and motivator for some students who were eager to learn more and achieve their ideas. It was because the native teachers always emphasized that education is the most important and most important thing for the future of students. In this study, students who were used as research subjects were the students from the suburban school, in this school not all students continued to higher education, many of them did not go to university. However, some of the students said that they were encouraged to study abroad and go to the higher education level after the native teacher shared her experiences and inspirations. One student claimed that native teacher encouraged him to keep learning, struggling and not afraid to dream big.

\section{The Native Teacher's Social Competence as Viewed by Students}

Teacher's social competence is the ability of a teacher to communicate effectively with the students (Haris, 2013) by showing her empathy, enthusiasm, and encouragement (Anugerahwati \& Saukah, 2010; Kiczkowiak, 2017). Indonesian Law No. 14/2005 state some criteria for being a teacher with good social competence. However, in this study, the researcher only took some of the criteria which can be viewed by the students, as shown in table 4. 
Table 4. The native teacher's social competence as viewed by students

\begin{tabular}{|c|c|c|c|c|c|c|c|c|}
\hline \multirow{2}{*}{ Statements } & \multicolumn{2}{|c|}{ SA } & \multicolumn{2}{|c|}{ A } & \multicolumn{2}{|c|}{ D } & \multicolumn{2}{|c|}{ SD } \\
\hline & $\mathbf{N}$ & $\%$ & $\mathbf{N}$ & $\%$ & $\mathbf{N}$ & $\%$ & $\mathbf{N}$ & $\%$ \\
\hline She always listens and appreciates students' opinions & 16 & 44.4 & 20 & 55.6 & & & & \\
\hline She respects racial, religious and cultural differences & 19 & 52.8 & 16 & 44.4 & 1 & 2.8 & & \\
\hline She always cares and helped students' learning difficulties & 9 & 25.0 & 25 & 69.4 & 2 & 5.6 & & \\
\hline She establishes good communication with students inside and outside the classroom & 7 & 19.4 & 28 & 77.8 & 1 & 2.8 & & \\
\hline
\end{tabular}

Both the data from the questionnaire and interview show that most of the students agreed if the native teacher always appreciated students' opinions by listening and showing her enthusiasm when the students were speaking and expressing their ideas. According to (Kelly \& Brandes, 2001) teachers play an important role in helping students appreciate multiple perspectives. Thus, it all started when the teacher gave an example to appreciate the different opinions among the students.

Moreover, almost the entirety of the students agreed that the native teacher never touched on the differences in race, religion, and culture because she highly respected the differences. The relationship between a teacher and others in the education community is based on how the teacher treats and respects others (Anugerahwati \& Saukah, 2010). Native teacher's experiences in teaching multicultural classes in America made her highly respected the differences between her and the students.

For the third statement which is stated that the native teacher was able to help the students' learning difficulties, some students stated agree for that statement. These students were those who had good achievements in English. They had more opportunities to ask questions both in the classroom and outside the classroom. According to Wong (2009), native teacher tends to be more successful in teaching advanced learners. However, for the students who lack both vocabulary and confidence to confirm their difficulties to the native teacher, yet most of the students claimed that the native teacher established good communication with students.

\section{CONCLUSION}

This study investigated the native teacher's professional competences as viewed by the students. The results of this present study indicate that the native teacher who is often regarded as an ideal teacher for teaching English apparently also had several deficiencies in subject matter knowledge. In terms of pedagogical competence, the native English speaker is absolutely an expert in using English, yet she could not definitely become an expert in teaching English. There were some deficiencies in teaching the EFL students which were completely different from her teaching experiences of the ESL students. Meanwhile, in terms of personal competence, many students agreed that native teacher had a good and friendly personality. Students also claim that she was a flexible person and always respect the differences in students' opinions and arguments. She was also a pleasant figure, even though in the classroom she was assertive and disciplined. In the case of social competence, it was known that native teacher always listened and appreciated students' opinions. She also highly respected the students' beliefs, values, racial, religious, and cultural differences. Thus, the native teacher always tried to establish good communication with students. In addition, this study also found that the native teacher seems to be more suitable to teach the advanced students since most of the lower achievers could not follow the native teacher's explanations and instructions.

\section{REFERENCES}

Al-Khairi, D. M. (2015). Qualities of an Ideal English Language Teacher: A Gender-Based Investigation in a Saudi Context. Journal of Education and Practice, 6(15), 12.

Anchimbe, E. A. (2006). The Native-Speaker Fever in English Language Teaching (ELT): Pitting Pedagogical Competence Against Historical Origin. Linguistics Online, 26(1), 13.

Anugerahwati, M., \& Saukah, A. (2010). Professional Competence of English Teachers in Indonesia: A Profile of Exemplary Teachers. Indonesian Journal of English Language Teaching, 6(2), 13.

Azma, M., \& Talebinejad, M. R. (2012). Teacher's Pedagogical Knowledge and Learner's Success in EFL Contexts. ELT Research Paper 2, 2(6).

Braine, G. (2010). Nonnative Speaker English Teachers: Research, Pedagogy, and Professional Growth (Second). New York \& London: Routledge.

Dewan Perwakilan Rakyat Republik Indonesia, \& Presiden Republik Indonesia. (2005). Undang-Undang Nomor 14 Tahun 2005 Tentang Guru dan Dosen.

Hu, G., \& Lindemann, S. (2009). Stereotypes of Cantonese English, Apparent Native/Non-Native Status, and Their Effect on Non-Native English Speakers' Perception. Journal of Multilingual and Multicultural Development, 30(3), $253-269$.

Jin, J. (2005). Which is Better in China, A Local or A Native English-Speaking Teacher? English Today, 21(3), 39-46. https://doi.org/10.1017 
Kelly, D. M., \& Brandes, G. M. (2001). Shifting out of "Neutral”: Beginning Teachers' Struggles with Teaching for Social Justice. Canadian Journal of Education / Revue Canadienne de l'éducation, 26(4), 437. https://doi.org/10.2307/1602176

Kiamba, E. W., Mutua, F., \& Mulwa, D. (2018). Influence of Teacher's Subject Matter Knowledge on Students' Academic Achievement of Kiswahili Language in Public Secondary Schools in Kathonzweni Sub-County, Kenya. Scholarly Research Journal for Interdisciplinary Studies, 6(29), 8.

Kiczkowiak, M. (2017). Confronting Native Speakerism in the ELT Classroom: Practical Awareness-Raising Activities. The European Journal of Applied Lingusitics and TEFL, 6(1), 30.

Krashen, S. D. (1985). Second Language Acquisition and Second Language Learning (Reprinted). Oxford: Pergamon Pr.

Maum, R. (2002). Non-Native English Speaking Teachers in the English Teaching Profession. Eric Digest. Eric Digest, EBSCO ERIC database (ED470982).

McKenzie, R. M. (2008). The Role of Variety Recognition in Japanese University Students' Attitudes Towards English Speech Varieties. Journal of Multilingual and Multicultural Development, 29(2), 139-153.

Medgyes, P. (2001). When the Teacher is a Non-Native Speaker. Teaching English as a Second or Foreign Language, $429-442$.

Reis, D. S. (2011). Non-Native English-Speaking Teachers (NNESTs) and Professional Legitimacy: A Sociocultural Theoretical Perspective on Identity Transformation. International Journal of the Sociology of Language, (208). https://doi.org/10.1515

Scales, J., Wennerstrom, A., Richard, D., \& Wu, S. (2006). Language Learners' Perceptions of Accent. TESOL Quarterly, 40(4), 715-738. https://doi.org/10.2307

Sudibyo, B. (2007). Peraturan Menteri Pendidikan Nasional Republik Indonesia Tentang Standar Kualifikasi Akademik dan Kompetensi Guru.

Timmis, I. (2002). Native Speaker Norms and International English: A Classroom View. ELT Journal, 56(3), $240-249$. https://doi.org/10.1093

Topal, P., \& Öztürk, F. (2017). Student and Teacher Perceptions about Native and Non-Native Speaker Teachers of English.

Van Canh, L., \& Renandya, W. A. (2017). Teachers' English Proficiency and Classroom Language Use: A Conversation Analysis Study. RELC Journal, 48(1), 67-81. https://doi.org/10.1177/0033688217690935

Wong, C. (2009). Are Native Speakers "Good” Language Instructors? A Case Study of Untrained ESL Tutors. ARECLS, 6, $122-140$. 